\title{
THE EFFECT OF MICROFINANCE BANK ON POVERTY ALLEVIATION, A SURVEY OF SELECTED MICROFINANCE BANK IN OSUN STATE
}

\author{
SHITTU SAHEED AKANDE \\ Department of Management and Accounting, LAUTECH, Ogbomoso \\ GBOLAGADE ADEKOLA SIKIRULAHI \\ Department of Management and Accounting, LAUTECH, Ogbomoso \\ EUNICE AFOLAKE \\ Department of Accounting and Finance, UNIOSUN, Osogbo \\ https://doi.org/10.37602/IJSSMR.2020.3407
}

\begin{abstract}
Microfinance schemes are seen as a means for poor households to gain access to muchneeded credit services that are appropriate for their needs. Therefore, this study examined the effect of microfinance bank on poverty alleviation in Osun State. The study adopted a descriptive design using a structured questionnaire as the main instrument for data collection. Regression analysis technique was used to test hypotheses. The study indicated that there is a positive significant relationship between Microfinance operations and poverty alleviation. It was also discovered that Micro-credit has a positive influence on poverty reduction and there is a significant relationship between the deposit of microfinance bank and poverty alleviation. Therefore, the study recommended that Government at all levels should give more support to microfinance bank in order to improve their performance. This will promote people economic capacity and bring sustainable development.
\end{abstract}

Keywords: Credit loan, Micro-credit, Micro-finance, Poverty.

\subsection{INTRODUCTION}

The credit policy for the poor involves many practical difficulties arises from operation followed by financial institutions and the economic characteristics and financing needs of low-income households. For example, commercial banking institutions require that borrowers have a stable source of income out of which principal and interest can be paid back according to the agreed terms. However, the income of many self-employed households is not stable. A huge number of microloans are needed to serve the poor, but a banking institution prefers dealing with big loans in small numbers to minimize administrative expenses. They also look for collateral with a clear title - which many low-income households do not have. In addition, bankers tend to consider low-income households a bad risk imposing exceedingly high 


\section{International Journal of Social Sciences and Management Review}

information monitoring costs on the operation. Three features distinguish microfinance from other formal financial products. These are; the smallness of loans advanced and or savings collected, the absence of asset-based collateral and simplicity of operations. Despite various studies on the subject topic, the question of the effectiveness and impact on the poor of microfinance programs is still highly in question (Westover, 2008). Roodman \& Morduch (2009) reviewed studies on micro-credit in Bangladesh, and similarly conclude that 30 years into the microfinance movement, there is little solid evidence that it improves the lives of clients in measurable ways. Even the World Bank Report Finance, (2007) indicates that 'the evidence from micro-studies of favourable impacts from direct access of the poor to credit is not especially strong.

In Nigeria, the proportion of people living in poverty has increased tremendously. For instance, in 1980, the magnitude of Nigerians living below the poverty line increased from $17.1 \mathrm{~m}(27.2 \%$ of $65 \mathrm{~m}$ total population) to $34.7 \mathrm{~m}$ in 1985 (46.3\% of the total population of $75 \mathrm{~m})$. The people living in poverty in 1992 were $39.2 \mathrm{~m}(42.7 \%$ of the total population of $91.5 \mathrm{~m})$. This figure increased to $67.1 \mathrm{~m}$ in 1996 (65.6\% of the total population of $102.3 \mathrm{~m})$. In 2004 , the people in poverty were $68.7 \mathrm{~m}$ (54.4\% of the total population of $126.3 \mathrm{~m})$, the proportion of people living below property line rose sharply in 2010 to $112.47 \mathrm{~m}$ (69\% of the estimated population of $163 \mathrm{~m})$

(National Bureau of Statistics, 2012) It is against the backdrop of the above-enumerated problems that this study is set to evaluate the contribution of microfinance to poverty alleviation in the study area and by extension in the entire Nigeria country. The development objective of microfinance for poor, small scale farming and fish farming, rural and urban communities is to enable them to increase their income, smoothen consumption, develop micro-enterprises, manage risks better and enhance their earning capacities, thus reducing their social and economic vulnerabilities. Against this background, this study examined the effect of microfinance bank on poverty alleviation, a survey of selected microfinance bank in Osun State. More specifically, the study assessed the impact of microfinance bank operation on poverty alleviation; examined the influence of micro-credit on poverty reduction and; determined the effect of deposit of microfinance bank on poverty alleviation. While the study developed and tested the following hypotheses:

Ho1: There is no significant relationship between microfinance operations and poverty alleviation.

Ho2: There is no significant relationship between the influence of micro-credit and poverty reduction.

Ho3: There is no significant relationship between the effect of deposit of microfinance bank and poverty alleviation.

\subsection{LITERATURE REVIEW}

\subsection{Poverty}

Poverty is a critical phenomenon that calls for an urgent attention and solution all over the world, especially in the underdeveloped nations of the world where it has eaten deep into the lives of many. Poverty is defined as lack of command over basic consumption needs, that is, 


\section{International Journal of Social Sciences and Management Review}

a situation of inadequate level of consumption; giving rise to insufficient food, clothing and shelter (Ravillion \& Bodani, 1994). Poverty is as old and as rife as humankind. A majority of the human race has always suffered intermittent hunger. What is not old is the fact that people all over the world are beginning to demand a betterment of their economic lot. According to the World Bank Organization, the most commonly used way to measure poverty is based on incomes. If a person's income level falls below a minimum level required to meet his basic needs, the person is considered poor. This minimum level is usually called the poverty line. According to Meyer (2001), historically poverty was viewed largely as a problem of the poor earning too little income, consuming too little to attain a socially acceptable standard of living and possessing too few assets to protect themselves against unforeseen problems. Poverty alleviation strategies, therefore, have usually focused on employment creation, sometimes skill acquisition and, occasionally, redistribution of assets from the rich to the poor, (Osuala \& Hamilton, 2009). Technological change for small farmers has been a part of most rural poverty programmes. Improving access to credit has often been viewed as an important weapon in the arsenal to fight rural poverty. Poverty reduction improves the quality of life of the people and provides them with the means to acquire and maintain their basic needs.

\subsection{Microfinance}

Microfinance can be defined as a type of financial development mainly dedicated to poverty reduction via the provision of financial services to the poor. The Canadian International Development Agency (2002) defined microfinance as, the provision of a wide spectrum of financial services to the low-income households and micro-enterprises who usually lack access to formal financial institutions. Though it is narrowly believed that microfinance is all about micro-credit (i.e. lending small amounts of money to the poor), microfinance is beyond that: it has a far-reaching perspective, which includes transactional services, insurance, and most importantly, savings. In the view of Brooks (2013), Microfinance refers to a collection of financial services, including credit, advance, money and insurance cover, accessible by poverty-stricken industrialists and small commercial proprietors who have no security and wouldn't otherwise meet the requirements for an average bank loan.

\subsection{Microfinance and Poverty Alleviation}

There is a debate about whether an impact assessment of microfinance projects is necessary or not. The argument is if the market gives sufficient proxies for impact, such that customers are pleased to pay for a service, then assessments are a waste of resources. However, this is too simplistic a rationale as market proxies mask the range of client responses and benefits to the Microfinance banks. Therefore, impact assessment of microfinance interventions is necessary, not just to demonstrate to donors that their interventions are having a positive impact, but to allow for learning with Microfinance banks so that they can improve their services and the impact of their projects (Mayoux \& Simanowitz, 2001). Poverty is beyond a lack of income. Wright and Rowe (1999) drew attention to the shortcomings of seeing increased income as the sole measure of the effect of microfinance on poverty. He argues that a significant difference exists between increased income and poverty alleviation. He argues further that by growing the incomes of the poor, microfinance institutions are not necessarily alleviating poverty. It is all a function of what these low-income people do with the money: 


\section{International Journal of Social Sciences and Management Review}

often it is spent on gambling or on alcohol. Thus focusing merely on growing incomes is not adequate.

The focus needs to be on helping the poor to have a particular quantum of well-being (Wright \& Rowe, 1999) by offering them a variety of financial services tailored to their needs so that their net wealth and income security can be improved. Dichter (1999) states that microfinance is a tool for poverty reduction and while arguing that the record of MFIs in microfinance is generally well below expectation, he does concede that some positive impact do take place. After a study of a number of microfinance institutions, the findings show that redistribution of wealth and consumption smoothing effects within the household are the commonest impacts of microfinance.

\subsection{Empirical Review}

Rena and Tesfy (2006) concluded that microfinance is the founding stone for poverty reduction. Their study showed that there is a fundamental linkage between microfinance and poverty eradication, in that the latter depends on the poor gaining access to, and control over, economically productive resources, which includes financial resources. Previously implemented programs not produced good results due to the non-involvement of the peoples for which the programs were designed (the poor).

The study conducted by Shirazi and Khan (2009) shows that two types poor were taken in consideration such as the poor and the extremely poor. The authors examined the impact of microcredit on poverty alleviation. Microcredit had reduced the overall poverty level by 3.07 percentage points (from 6.61 per cent to 3.54 per cent) and the borrowers have shifted to higher income groups during the reported period. The poverty status of the extremely poor borrowers has been marginally increased (by 0.63 percentage point), showing obviously no effect of microcredit on the poverty status of these households.

Gopalan (2007) opened that microfinance increases the self-confidence of the poor by meeting their emergency requirements, ensuring need-based timely credits and making the poor capable of savings. The study also shows the credibility of microfinance in healthrelated issues in a positive manner. The work of Ali and Alam (2010) revealed that Microfinance is the most important resource to provide loans and other basic financial services to increase the employment rate, productivity and earning capacity. It will impact people's lives through removing poverty, improving living standards, such as health, education, food and other social impacts. The microfinance sector is developed day by day in Pakistan. Most of the population of Pakistan is based on the rural area, where people live below the poverty line.

\subsection{METHODOLOGY}

The study adopted a descriptive design using a structure questionnaire as the main instrument for data collection. Regression analysis technique was used to test the hypothesis. Eight (8) microfinance banks are in Osogbo as at the date, the capital city of Osun State out of which the following five (5) were randomly selected. Lapo Microfinance Bank Limited Osogbo, Omak Microfinance Bank Limited Osogbo, NPF Microfinance Bank Limited Osogbo, KJL 


\section{International Journal of Social Sciences and Management Review}

Microfinance Bank Limited Osogbo, Osogbo Microfinance Bank Limited Osogbo. The model used in the study was adopted from Egbulonu (2000) and is presented as follows.

$\mathrm{Y}=\mathrm{a} 0+\mathrm{a} 1 \mathrm{X} 1+\mathrm{a} 2 \mathrm{X} 2 \ldots \ldots \ldots \mathrm{an} \mathrm{Xn}+\mu$.

Hence PCI - F(LADt1 DMFBt),

i.e $\quad \mathrm{PCI}=\mathrm{a} 0+\mathrm{a} 1 \mathrm{LAD}+\mathrm{a} 2 \mathrm{DMFB}+\mu$

PCI $=a 0+a 1 L A D+a 2 D M F B$

Where:

$\mathrm{PCI}=$ Per Capita Income (Y)

LAD $=$ Loans and Advances of Micro Finance Banks (X1)

$\mathrm{DFMB}=$ Deposits of Micro Finance Banks (X2)

$\mu \quad=$ Stochastic Variable.

\subsection{RESULT AND DISCUSSION}

Table 1

\begin{tabular}{|c|c|c|c|c|c|c|c|}
\hline \multicolumn{6}{|c|}{ Alleviation $^{a}$} & \multicolumn{2}{|c|}{ Model Summary } \\
\hline Variable & Label & Parameter Estimate & Standard Error & t Value & $\operatorname{Pr}>|t|$ & & \\
\hline \multirow[t]{2}{*}{ Intercept } & Intercept & 0.46208 & 0.14613 & 3.16 & 0.0021 & R-Square & 0.8408 \\
\hline & $\begin{array}{l}\text { Microfinance } \\
\text { Operations }\end{array}$ & 1.04706 & 0.04674 & 22.40 & $<.0001$ & Adj R-Square & 0.8391 \\
\hline
\end{tabular}

Source: Researcher's Computation, 2020

a. Predictors: (Constant), Microfinance Operations.

b. Dependent Variable: Poverty Alleviation.

Table 1 shows the impact of microfinance operations on poverty alleviation. Microfinance operations enhance poverty alleviation by 84.08 percent. As depicted in table 1 , the estimates of the model coefficients for $\beta 0$ (Intercept) is 0.46208 , and $\beta 1$ (Microfinance Operations) is 1.04706 .

Poverty Alleviation $=0.46208+1.04706$ Microfinance Operations

The regression equation shows that the relationship between Microfinance Operations and Poverty Alleviation is positive. 0.46208 is the average value of poverty alleviation when the impact of microfinance operations is constant. It also shows the increase in poverty alleviation is due to the per unit increase in microfinance operations. If microfinance operations are increased by 1 unit the average change in poverty alleviation will increase by 1.04706.

\section{Decision Rule}




\section{International Journal of Social Sciences and Management Review}

"Reject the null hypothesis if the value of $\mathrm{t}$-calculated is greater than the value of t-tabulated $\left(t_{c a l}>t_{t a b}\right)$, otherwise accept it. At $95 \%$ level of significance $(\alpha=0.05)$ ".

The $\mathrm{t}$-calculated is given as 22.40

The t-tabulated is given as: $\mathrm{t} 0.05,(97)=1.98472318$.

\section{Decision}

Since $\mathrm{t}$-calculated $=22.40>\mathrm{t}$-tabulated $=1.98472318$. We reject the null hypothesis. In conclusion, the results of the regression confirm with $95 \%$ confidence that microfinance operations have a positive significant impact on poverty alleviation.

Table 2.

\begin{tabular}{|l|l|l|l|l|l|l|l|l|}
\hline \multicolumn{2}{|l|}{ Table 8.2: Summary of Regression Analysis of Micro-credit on Poverty reduction ${ }^{\mathrm{a}}$} & \multicolumn{2}{l|}{ Model Summary $^{\mathrm{b}}$} \\
\hline Variable & Label & Parameter Estimate & Standard Error & $t$ Value & $\operatorname{Pr}>|t|$ & & \\
\hline Intercept & Intercept & 0.56439 & 0.11810 & 4.78 & $<.0001$ & R-Square & 0.7695 \\
\hline & Micro-credit & -0.74121 & 0.04162 & -17.81 & $<.0001$ & Adj R-Square & 0.7671 \\
\hline
\end{tabular}

Source: Researcher's Computation, 2020

a. Predictors: (Constant), Micro-credit.

b. Dependent Variable: Poverty reduction.

Table 2 shows the influence of Micro-credit on poverty reduction is presented in table 2; micro-credit have $76.95 \%$ influence on poverty reduction. As shown in table 2 , the estimates of the model coefficients for $\beta 0$ (Intercept) is 0.56439 , and $\beta 1$ (Micro-credit) is -0.74121 . Therefore, the estimated model between Micro-credit and Poverty Reduction is presented thus:

Poverty Reduction $=0.56439-0.74121$ Micro-credit .

The regression equation shows that the relationship between Micro-credit and Poverty Reduction is negative. 0.56439 is the average value of poverty reduction when the influence of micro-credit is constant. Table 2 shows the decrease in poverty is due to the per unit increase in micro-credit. If micro-credit is increased by 1 unit the average change in poverty will decrease by 0.74121 .

\section{Decision Rule}

"Reject the null hypothesis if the value of $\mathrm{t}$-calculated is greater than the value of t-tabulated $\left(t_{c a l}>t_{t a b}\right)$, otherwise accept it. At $95 \%$ level of significance $(\alpha=0.05)$ ".

The $\mathrm{t}$-calculated is given as 17.81

The t-tabulated is given as: t0.05, $(97)=1.98472318$. 


\section{International Journal of Social Sciences and Management Review}

\section{Decision}

Since $\mathrm{t}$-calculated $=17.81>\mathrm{t}$-tabulated $=1.98472318$. We reject the null hypothesis. In conclusion, the results of the regression confirm with $95 \%$ confidence that micro-credit has an influence on poverty reduction.

Table 3

\begin{tabular}{|c|c|c|c|c|c|c|c|}
\hline \multicolumn{6}{|c|}{$\begin{array}{l}\text { Table 8.3: Summary of Regression Analysis of Deposit of microfinance bank on } \\
\text { Poverty Alleviation }\end{array}$} & \multicolumn{2}{|c|}{ Model Summary } \\
\hline Variable & Label & Parameter Estimate & Standard Error & t Value & $\operatorname{Pr}>|t|$ & & \\
\hline \multirow[t]{2}{*}{ Intercept } & Intercept & 1.07220 & 0.07932 & 13.52 & $<.0001$ & R-Square & 0.8842 \\
\hline & $\begin{array}{l}\text { Deposit of } \\
\text { microfinance } \\
\text { bank }\end{array}$ & 0.76189 & 0.02828 & 26.94 & $<.0001$ & Adj R-Square & 0.8830 \\
\hline
\end{tabular}

Source: Researcher's Computation, 2020

a. Predictors: (Constant), Microfinance Operations.

b. Dependent Variable: Poverty Alleviation.

The summary of the effect of deposit of microfinance bank on poverty alleviation is presented in Table 3; deposit of microfinance bank affects poverty alleviation by 88.42 percent. As shown in Table 3, the estimates of the model coefficients for $\beta 0$ (Intercept) is 1.07220 , and $\beta 1$ (Deposit of microfinance bank) is 0.76189 . Therefore, the estimated model between Deposit of microfinance bank and Poverty Alleviation is presented thus:

Poverty Alleviation $=1.07220+0.76189$ Deposit of microfinance bank .

The regression equation shows that the relationship between the Deposit of microfinance bank and Poverty Alleviation is positive. 1.07220 is the average value of poverty alleviation when the impact of deposit of microfinance bank is constant. Table 3 shows the increase in poverty alleviation is due to the per unit increase in deposit of microfinance bank. If the deposit of microfinance bank is increased by 1 unit the average change in poverty alleviation will increase by 0.76189 .

\section{Decision Rule}

"Reject the null hypothesis if the value of $\mathrm{t}$-calculated is greater than the value of t-tabulated $\left(t_{c a l}>t_{t a b}\right)$, otherwise accept it. At $95 \%$ level of significance $(\alpha=0.05)$ '”

The $\mathrm{t}$-calculated is given as 26.94

The $\mathrm{t}$-tabulated is given as: $\mathrm{t} 0.05,(97)=1.98472318$. 


\section{International Journal of Social Sciences and Management Review}

\section{Decision}

Since $\mathrm{t}$-calculated $=26.94>\mathrm{t}$-tabulated $=1.98472318$. We reject the null hypothesis . In conclusion, the results of the regression confirm with $95 \%$ confidence that the deposit of a microfinance bank has a significant effect on poverty alleviation.

\subsection{CONCLUSION AND RECOMMENDATION}

Based on the empirical analysis of the hypotheses of the study, it was discovered that microfinance operations have a significant impact on poverty alleviation. Since the provision of funds in form of credit and microloans empowers the poor to engage in productive economic activities which can help boost their income level and thus alleviate poverty in the economy. The study revealed that Microfinance operations have positive significant relationship on poverty alleviation. This implies that the activities of microfinance bank have a positive effect in reducing poverty. It was also discovered that Micro-credit has a positive influence on poverty reduction, which means that microfinance banks give out more loans to its customers to reduce poverty and there is a significant relationship between the deposit of microfinance bank and poverty alleviation, this indicates an increase in the deposit of microfinance bank will propel a reduction in poverty.

The analysis of the result in the study provides evidence that micro-credit has an influence on poverty reduction. The result is in disagreement with the findings of Roodman \& Morduch (2009) which in their study concluded that 30 years into the microfinance movement they have little solid evidence that it improves the lives of clients in measurable ways. This study has established the fact that deposit of microfinance bank has a significant effect on poverty alleviation. This result lends credence to the fact that microfinance is an effective development tool for promoting pro-poor growth and poverty reduction. Financial services enable poor and low-income households to take advantage of economic opportunities, build assets, and reduce their vulnerability to external shocks that adversely affect their living standards. Therefore, the study recommended that Microfinance bank should improve their operations in order to perform more efficiently and effectively since microfinance programs have the potential to alleviate poverty especially in increasing level of income and reducing vulnerability. Also, Government at all levels should give more support for Microfinance bank in terms of giving them a loan with low-interest rate and the easy policy and guidelines to microfinance bank in order to improve their performance. This will promote people economic capacity and bring sustainable development.

\section{REFERENCES}

Ali, A., \& Alam, M. A. (2010). Role and Performance of Micro-credit in Pakistan. International Journal of Business, 2(9): 1-4.

Brooks, C. (2013). "What is Microfinance?" Retrieved from: http://www.businessnewsdaily.com/4286-microfinance.

Canadian International Development Agency (2002). CIDA and microfinance: A poverty reduction approach, Policy Branch. A Research Journal of Finance \& Accounting, 4(10): 28-37. 


\section{International Journal of Social Sciences and Management Review}

Volume: 03, Issue: 04 "July - August 2020"

ISSN 2582-0176

Dichter, T. W. (1999). NGOs in microfinance: Past, present and future. In Microfinance in Africa, Breth, S. A. (Eds). Mexico City: Sasakawa Africa Association. pp: 12-37.

Gopalan, S. S. (2007). Micro-finance and its Contributions to Health Care Access (A Study of Self-Help Groups (SHGS) in Kerala). Health and Population Department of Kerala on Health and Population,

Mayoux, L. \& Simanowitz, A. (2001). Small enterprise foundation. South Africa: EDIAIS.

Meyer, R. L. (2001). Microfinance, rural poverty alleviation and improving food security ADB 2(2).

National Bureau of Statistics (2012). Nigeria poverty profile 2010.

Osuala, A. E \& Hamilton, O. I. (2009). Microfinance \& rural poverty alleviation in Nigeria; The Coca - Cola \& Haier Model. Journal of Finance, Banking and Investment, $3(1): 145-152$

Ravillion, M, and Bodani, B. (1994). How robust is a poverty profile? World Bank Economic Review. Oxford University Press, 8(1): 75-102.

Rena, R. \& Tesfy, G. (2006). Poverty and microfinance in Eritrea -a discourse. The Global Journal of Finance and Economics, 4(2): 80-86

Rodman, D. \& Morduch, J. (2009). The impact of micro-credit on the poor in Bangladesh: revisiting the evidence (working paper no174). Washimgton DC: Centre for Global Development.

Shirazi, N. S. \& Khan, A. U. (2009). Role of Pakistan Poverty Alleviation Fund's and Micro Credit in Poverty Alleviation (A case of Pakistan). Pakistan Economic and Social Review.

Shreinner, (2001). Aspect of financial outreach: A framework for the Discussion of the Social Benefiit of Microfinance.

Westover, J. (2008). The record of microfinance: the effectiveness /ineffectiveness of microfinance program as a means of alleviating poverty,

World Bank (2007). Finance for all? Policies and pitfalls in expanding access. Washington D.C World Bank.

Wright, G. and G. Rowe, (1999). The Delphi technique as aforecasting tool: Issues and analysis. International Journal of Forecasting. 